Acta Regionalia et Environmentalica 1

Nitra, Slovaca Universitas Agriculturae Nitriae, 2016, pp. 22-26

\title{
MEASURING DEVELOPMENT OF SELECTED POVERTY RISK INDICATORS IN V4 COUNTRIES WITH SPECIFIC FOCUS ON SLOVAK REPUBLIC AND ITS REGIONS
}

\author{
Ondrej BEŇUŠ*, Marián KOVÁČIK, Eva ŽUFFOVÁ \\ Slovak University of Agriculture in Nitra, Slovak Republic
}

\begin{abstract}
This article is devoted to analysis of selected poverty indicators as measured by EU-Statistics on income and living conditions. Our orientation on these indicators underlines our focus on quantitative measurement. Spatial orientation was selected as the area of the Visegrad group countries serving as a research base for our investigation of poverty differences in the Central Europe. Further research is dedicated to Slovakia and its regions. In this article we aim to identify those quantitative poverty indicators that are responsible for poverty status of the most affected social group of people in the country.
\end{abstract}

Keywords: material deprivation, at risk of poverty rate, low work intensity

In 2010 the EU member states committed to fulfil priorities of EUROPA 2020 strategy. Considering the state of global economy and the relevant pressure on employment, these priorities were oriented on restart of economy and suppression of risk of poverty in the member states. Nowadays, the above mentioned strategy is in the second half of planned fulfilment. On this occasion we decided to focus on the progress of poverty reduction of poverty and social exclusion in countries of the Visegrad Group. In case of Slovakia we focus on different development of individual indicators forming the Aggregate indicator of poverty and social exclusion.

The EUROPE 2020 strategy, also known as the strategy for smart, sustainable and inclusive growth, was adopted by the European Council in the year 2010. It is the successor to the Lisbon strategy from the year 2000, which was not particularly successful in fulfilling its main targeted goal in the form of transforming the European Union into "the most competitive and dynamic knowledge based economy in the world" to the year 2010 .

Soon after the autumn 2008 and Lehman Brothers filing for Chapter 11, protection against creditors, it was obvious, that these events will spill over to the rest of the world. Under these circumstances, there was no space left for the growth of the European economies for next few years and fulfilling the Lisbon strategy until the year 2010.

The Europe 2020 strategy, unlike the Lisbon strategy, was compiled as a plan of economic consolidation in the European Union. Representatives of the EU member states were facing growing rate of unemployment, public debt and stagnating economies. With this in mind, the Europe 2020 strategy was based on three priorities:

- smart growth,

- sustainable growth,
- inclusive growth.

Smart growth represents economies "based on knowledge and innovation". Sustainable growth is focusing attention on "more resource efficient, greener and more competitive economy". Inclusive growth stands for "highemployment economy delivering social and territorial cohesion".

Respecting theses three priorities, five targets of this strategy are established with focus on:

- Employment (Population aged from 20 to 64 years should be employed at a rate of $75 \%$ ).

- Research and development (Countries should invest 3\% of national GDP in research and development).

- Climate change and energy sustainability (Lowering the greenhouse gas emissions by $20 \%$ (compared to the year 1990), achieving $20 \%$ energy of renewable sources and $20 \%$ energy efficiency growth).

- Education (Reducing early school leaving under $10 \%$ and achieving a rate of $40 \%$ people aged between $30-34$ years with completed third level education).

- Fighting poverty and social exclusion (Lowering the number of citizens in or at risk of poverty or social exclusion by 20 million).

According to this strategy, the European Union should lower the number of people in or at risk of poverty and social exclusion by 20 million people, which represents about $25 \%$ (According to the EUROPE 2020 document there were about 80 million people in or at risk of poverty and social exclusion in the European Union in year 2010).

Poverty can be defined as "a condition where a person feels a lack of either money or material goods" (Schwarcz and Kováčik, 2012). Definitions of poverty are influenced by two approaches. First approach defines relative poverty. Peter Townsend (1979) pioneered in this 


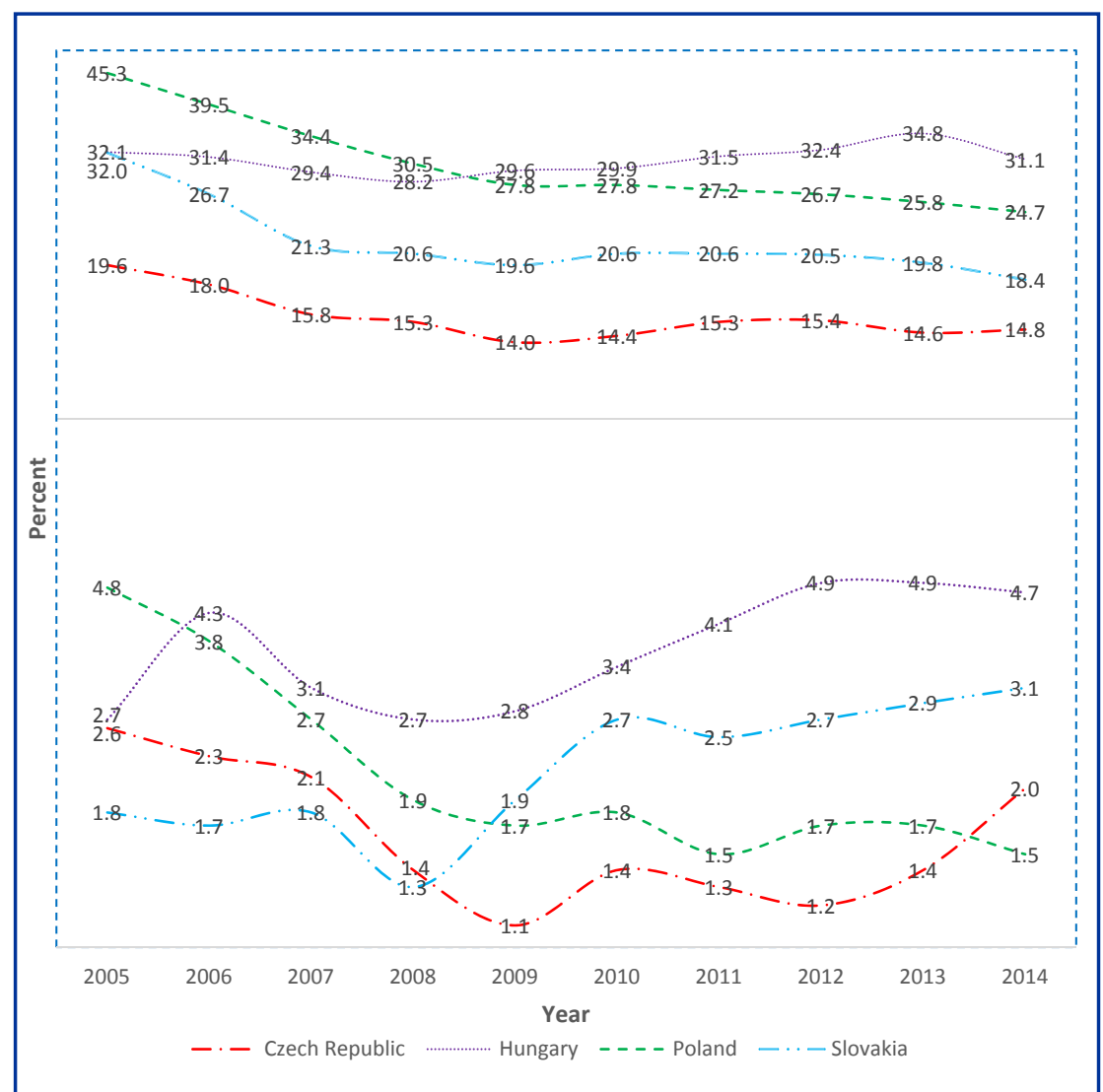

Figure 2 People in or at risk of poverty and people exposed to all three subindicators

Source: Eurostat, processed by authors field. He defined poverty when the "individuals, families and groups in the population can be said to be in poverty when they lack the resources to obtain the types of diet, participate in the activities and have the living conditions and amenities which are customary, or are at least widely encouraged or approved, in the societies to which they belong. Their resources are so seriously below those commanded by the average individual or family that they are, in effect, excluded from ordinary living patterns, customs and activities" (Townsend, 1979).

Absolute approach to poverty is a reaction to the above mentioned relative approach. Among most significant authors belongs Amartya Sen, who strongly criticised relative approach to poverty. Sen stated, that is superior to the income method, since the former is not based on particular assumptions of consumption behaviour which may or may not be accurate" (Sen, 1981).

This target is monitored by EUROSTAT with help of indicator "in an obvious sense the direct method work intensity. Parallel to the AROPE indicator, this specific intersection of three sub-indicators of aggregate indicator of people in or at risk of poverty or social exclusion, the highest values were measured in Hungary. But the highest relative growth was experienced in Slovakia and this fact is in contradiction with the trend curve of AROPE indicator. Measured values (Figure 1) show the most significant growth from 2008 to 2010. In the following text we will decompose the AROPEindicatortothreesub-indicators. With these individually collected data we can identify the specific indicator responsible for the growing number of people mostly affected by poverty and social exclusion (all three measured sub-indicators measured by AROPE indicators).

\section{Material and methods}

The aim of this paper is to show the development of the Aggregate indicator of people at risk of poverty and social exclusion (AROPE) in the Visegrad Group in accordance with the priorities set in EUROPA 2020 strategy.

According to the EU-Statistics on Income and Living Conditions the AROPE indicator is composed of:

- At risk of poverty indicator.

- Material deprivation indicator.

- Low work intensity indicator.

A group of people endangered by all three sub-indicators of AROPE represents the most endangered part of population which should be in focus of government when creating employment and social inclusion policies. For this reason we also point out the development of this rate in the studied countries. Particular attention is paid to Slovakia where we study individual partial indicators of AROPE.

The data were collected by empirical comparison of secondary data and the used sources were statistical offices of Slovakia and the EU. The AROPE indicator was measured on national level and partial indicators were measured on NUTS II or NUTS III levels (depending on the data availability).

At risk of poverty indicator shows share of population in per cent, whose disposable income is under poverty threshold, it means $60 \%$ of median people affected by the risk of pove material deprivation and living in households with very low 
on national equivalent disposable household income. The term "poverty" defines men's social status, which is characterized by material lack. The problem of poverty is also present in developed countries and is considered as a global problem. To measure poverty we can use various approaches. In the EU, the poverty is defined by disposable income. Income inequality is amended by measuring of social exclusion in poverty. The EU member states use to determine the rate of poverty and social exclusion harmonized statistical survey on income and living conditions - EU SILC. This survey represents a significant source of information for mutual comparison of the EU countries. In Slovakia, this survey is done by the Statistical office of the Slovak republic.

Material deprivation rate represents a share of population which must face the enforced lack of 3 or 4 of 9 material deprivation items in the economic strain and durables dimension. This concept is defined by the following items: arrears on mortgage or rent payments, capacity to afford paying for one week's annual holiday away from home, capacity to face unexpected financial expenses and ownership of kinds of durable goods.

The definition of material deprivation is based on the inability to afford a selection of items that are considered to be necessary or desirable, namely:

- having arrears on mortgage or rent payments, utility bills, hire purchase instalments or other loan payments;

- not being able to afford one week's annual holiday away from home;

- not being able to afford a meal with meat, chicken, fish (or vegetarian equivalent) every second day;

- not being able to face unexpected financial expenses;

- not being able to buy a telephone (including mobile phone);

- not being able to buy a colour television;

- not being able to buy a washing machine;

- not being able to buy a car;

- not being able to afford heating to keep the house warm (SO SR).

The indicator persons living in households with low work intensity is defined as the number of persons living in a household having a work intensity below a threshold set at 0.20 .

The work intensity of a household is the ratio of the total number of months that all working-age household members have worked during the income reference year and the total number of months the same household members theoretically could have worked in the same period. A working-age person is a person aged 18-59 years, with the exclusion of students in the age group between 18 and 24 years. Households composed only of children, of students aged less then 25 and/or people aged 60 or more are completely excluded from the indicator calculation (SO SR).

We have calculated Pearson's correlation to stress association between the selected variables. The formula can be expressed as ( $x$ and $y$ represent two measured variables):

$$
r=\frac{\sum(x-\bar{x}) \cdot(y-\bar{y})}{\sqrt{\sum(x-\bar{x})^{2} \cdot \sum(y-\bar{y})^{2}}}
$$

Pearson's correlation can be measured between values $r=-1$ and $r$ $=1$. The value $r=-1$ represents maximal negative correlation and the value $r$ $=1$ maximal positive correlation. To describe verbally measured correlation we use followed classification (Evans, 1996):

$$
\begin{aligned}
& \text { 0.00-0.19: very weak, } \\
& \text { 0.22-0.39: weak, } \\
& \text { - 0.40-0.59: moderate, } \\
& \text { - 0.60-0.79: strong, } \\
& \text { - 0.80-1.00: very strong. }
\end{aligned}
$$

\section{Results and discussion}

\section{At risk of poverty indicator}

We studied at risk-of-poverty rate after social transfers in Slovakia on NUTS III level. This indicator represents share of population in per cent, whose disposable income is under poverty threshold, which is $60 \%$ of median on national equivalent disposable household income.

At the beginning of the reviewed period, the lowest rate of poverty was seen in the Bratislava region at the level of $6.5 \%$. A slightly higher rate was measured in the regions of Nitra and Banská Bystrica.

The highest rate of poverty was measured in the Prešov region at the level of $16.3 \%$. In 2010, 12\%, which accounted for over 650 thousand of Slovak citizens were endangered by poverty. The next year this number was increased by about $1 \%$. The highest number of people at risk of poverty was in 2012 and again the majority was found in the Prešov region (20.2\%).

The year 2013 meant slight improving of this situation, when $12.8 \%$ of Slovak citizens was at risk of poverty. The lowest rate was measured in the Bratislava region, where only $8 \%$ of citizens were at risk of poverty. According to EU SILC, in 2014 the share of population at risk of poverty represented $12.6 \%$, which accounted for 660 thousand of Slovak citizens.

During analysing this period we can state that from long term point of view the most endangered people

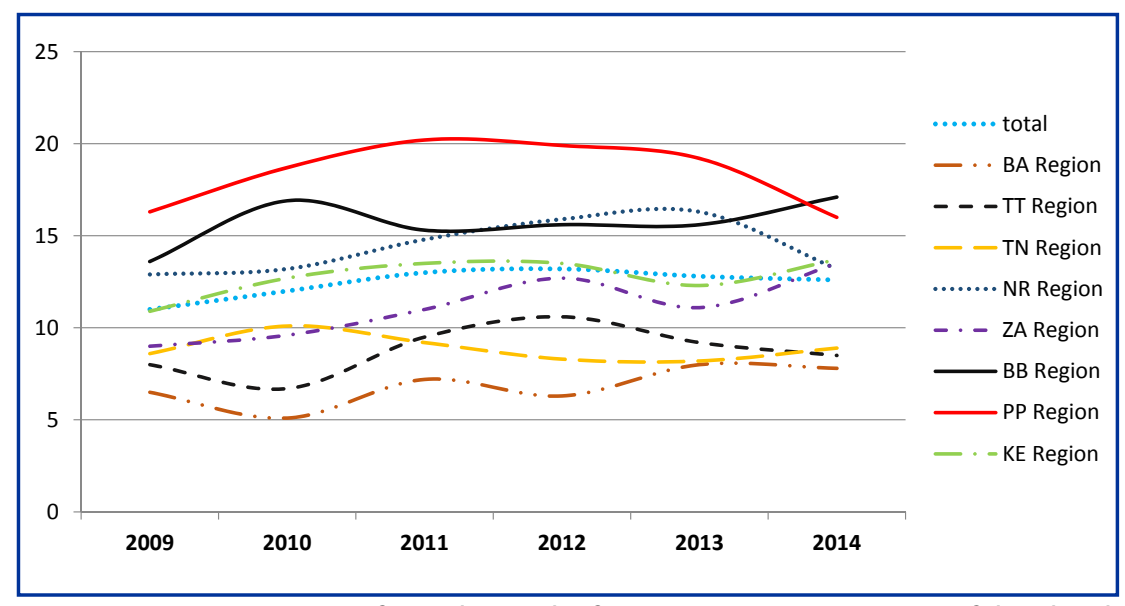

Figure 2 Percentage of people at risk of poverty in NUTS 3 regions of the Slovak Republic from 2009 to 2014

Source: Statistical office of Slovak Republic, modified by authors 


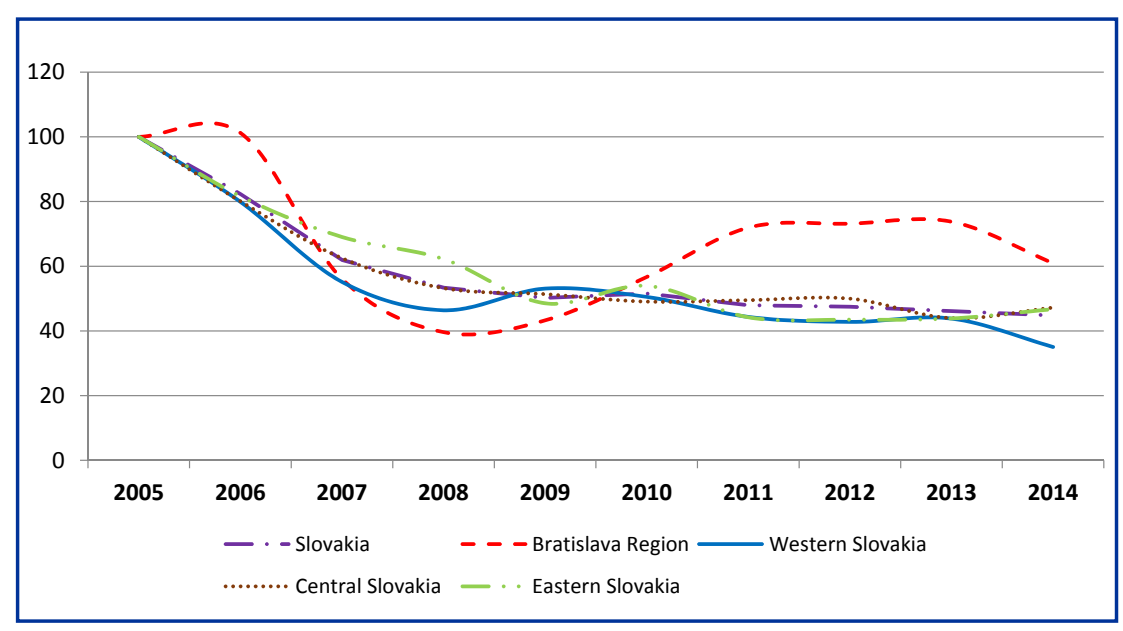

Figure 3 Material deprivation in Slovakia at NUTS II level between 2005-2014 Source: Statistical office of the Slovak Republic, modified by authors

Table 1 Low work intensity indicator in region of Slovakia from 2010 to 2014 in $\%$

\begin{tabular}{|l||c|c|c|c|c|}
\hline Region & $\mathbf{2 0 1 0}$ & $\mathbf{2 0 1 1}$ & $\mathbf{2 0 1 2}$ & $\mathbf{2 0 1 3}$ & $\mathbf{2 0 1 4}$ \\
\hline \hline Bratislava Region & 2.6 & 3.3 & 2.5 & 2.9 & 1.9 \\
\hline Trnava Region & 4.1 & 6.4 & 5.3 & 4.9 & 4 \\
\hline Trenčín Region & 5.7 & 5.3 & 5.1 & 4.5 & 4 \\
\hline Nitra Region & 10.7 & 11.3 & 10.2 & 10.2 & 6 \\
\hline Žilina Region & 4.2 & 4.1 & 4.5 & 3.3 & 6.3 \\
\hline Banská Bystrica Region & 12.9 & 11.3 & 11.1 & 12.3 & 12.6 \\
\hline Prešov Region & 11.7 & 9.8 & 9 & 11.7 & 11.4 \\
\hline Košice Region & 9.4 & 8.2 & 8.5 & 8.6 & 8.2 \\
\hline
\end{tabular}

Source: Statistical office of the Slovak Republic, EU SILC from 2010 to 2014, modified by authors

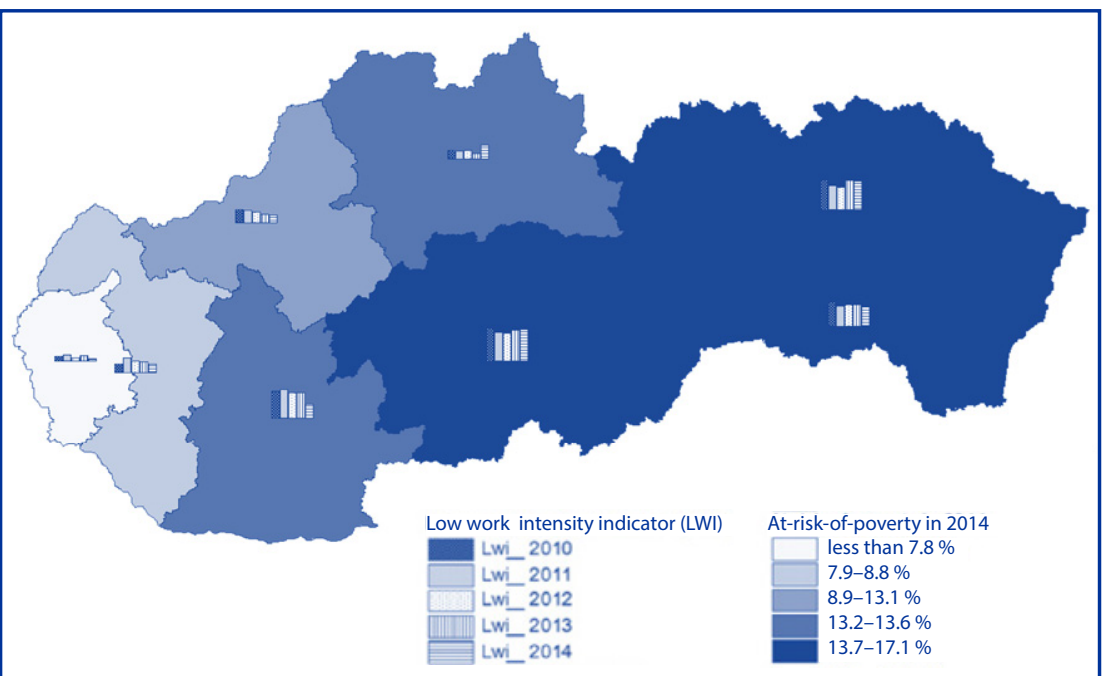

Figure 4 Low work intensity indicator and people at risk of poverty in Slovakia at NUTS 3 level

Source: Statistical office of the Slovak Republic, modified by authors at risk of poverty lived in the Prešov region. In the regions of Trnava, Trenčín and Žilina these rates were below Slovak average. Above Slovak average were the regions of Nitra and Banská Bystrica. The lowest rate was measured in the Bratislava region. During the period of financial crisis, there was a slight decrease of this indicator in more developed regions of Slovakia while in less developed regions this indicator was rising.

\section{Material deprivation indicator}

We analysed this indicator in detail in Slovakia on NUTS II level. The most significant changes in development of material deprivation were recorded in the Bratislava region. In 2006, the highest rate was measured in the Bratislava region. The decrease occurred during the following years with the lowest rate in 2008. During the following years, it started to increase again and later stopped in 2013. From this year onwards, it has decreasing tendency. The development of this indicator in other NUTS II regions was not very fluctuating during the whole period when it had decreasing tendency in all regions.

\section{Low work intensity indicator}

During the period from 2010 to 2014, the low work intensity indicator (LWI) had a fluctuating development in Slovakia. When analysing this indicator, we used two approaches. In case of national development, we compared the values of this indicator and when comparing regional (NUTS III) development, we analysed the development trend. The LWI indicator was in 2014 higher by about $0.5 \%$ than in 2005. The most significant increase was in 2010, when it was about 2.3\% higher than in 2005. From 2010 to 2014, the LWI had decreasing tendency. On national level, this indicator decreased by about $0.8 \%$. The most significant decrease was in the Nitra region, about $4.7 \%$. In all regions, except for the Žilina region, the LWI decreased. When taking a closer look we can see the development in all regions in Slovakia.

The highest fluctuation was in the Bratislava region when the yearly development trends were changing from $+26.92 \%$ to $-38.46 \%$. Extreme values were measured in the regions of Trenčín and Žilina. While in the Trenčín 
region there was an extreme increase by about $56 \%$ and gradual decrease to 2010 level, in Žilina, the increase was constant until 2012 then steep decrease below the 2010 level and in 2014 steep increase which meant that in 2014 the population with low work intensity was about 33\% higher than in 2010. The slight fluctuation was also seen in the regions of Banská Bystrica, Prešov and Košice. While in Košice the population level with LWI was below the 2010 level in other mention regions it was almost the same as in 2010. Only in the regions of Trenčín and Nitra the LWI had decreasing tendency.

We also analysed correlation between the group of inhabitants exposed to all three sub-indicators of the AROPE indicator and unemployment rate in the Slovak Republic using the Pearson correlation method. We used available data between the years 2005 to 2014. During this time period, we measured positive correlation rate of 0.466 , which represents only moderate correlation. In the case of second measurement we have compared the minimal wage in the Slovak Republic instead of the unemployment rate at national level. This measurement was also based on data available from the years 2005 to 2014. This correlation coefficient containing minimal wage has shown positive correlation rate of 0.882 , which represents very strong correlation. After this comparison (unemployment rate and minimal wage) we have come to the conclusion that wage structure in national economy is more important than unemployment rate, when analysing causes of poverty among people mostly affected by poverty (by all three AROPE indicators simultaneously).

\section{Conclusion}

Our examination of poverty development in four countries in the Central Europe shows positive development in this field (except of Hungary). These findings create good position for the mentioned countries for the next years in terms of fulfilling the EUROPE 2020 strategy. New member states (especially states which joined the European Union in the year 2004) have shown opposite trend to the old EU member states (EU 15), where the number of people in or at risk of poverty or social exclusion has had growing tendency (According to the Eurostat surveys countries with the highest growth are Greece, Spain and Portugal.) (especially for last 5-6 years).

Specific trends were experienced in Slovakia, where the intersection of three poverty and social exclusion indicators and AROPE were in contradiction. Measurement of correlation between number of people exposed to all three indicators defining poverty or social exclusion and unemployment rate has shown only moderate positive correlation $(r=0.466)$. On the other hand, correlation between intersection of these three indicators and the minimal wage in Slovakia has shown very strong positive correlation $(r=0.882)$. According to our findings, growing rate of people affected by intersection of the three indicators of poverty and social exclusion can be assigned to low work intensity indicator. This fact brings us to the conclusion that policies oriented on unemployment rate were not successful in lowering the number of people affected by intersection of the three indicators defining poverty and social exclusion. On the other hand, this group of population was more sensitive to the growing minimal wage set by parliament through legislation process. With this knowledge in mind some measures should be adopted, especially those with influence on tax burden of entrepreneurs. There is a need of even higher motivation of entrepreneurs with employees whose salaries are in the field of minimal wage set by law.

National and regional poverty indicators reflect the current economic situation. The only way to improve situation is to boost work on better business environment. Especially in Slovakia, we see space for improvement of legislation environment. Following the Small Business Act, all Member states should apply legislation favourable for small and middle enterprises. This is a crucial task for lawmakers when this size group of enterprises is the main employer in economy. Foreign direct investments can be seen as another source of poverty differences. In this case, we have to mention especially spatial differences among regions in this field of investments.

Again, we want to point out that we based our research on quantitative indicators used by EU-Statistics on income and living conditions. For more detailed investigation, it is necessary to make thorough research based on qualitative poverty indicators. This kind of research requires more

\section{References}

detailed investigation which was not possible to be covered by the given article limits.

BECKERMAN, W. 1979. Poverty and the impact of income maintenance programmes. Geneva : International Labour Organization, 1979, 90p. ISBN 92-2-102063-0.

EÚ SILC. 2010. Indikátory chudoby a sociálneho vylúčenia. Bratislava : Štatistický úrad Slovenskej republiky, 2011, 25 s. ISBN 978-80-89358-77-9.

EÚ SILC. 2011. Indikátory chudoby a sociálneho vylúčenia. Bratislava : Štatistický úrad Slovenskej republiky, 2012, 26 s. ISBN 978-80-8121-135-5.

EUROSTAT. 2016. Retrieved February 9, 2016 from http:// ec.europa.eu/eurostat/statistics explained/index.php/Glossary: At_risk_of_poverty_or_social_exclusion_(AROPE)

EVANS, J. D. 1996. Straightforward Statistics for the Behavioral Sceinces. CA : Boks/Cole Pub Co., 1995, 624 p. ISBN 978-0534231002.

GIDDENS, A. 2013. Sociologie. Praha : ARGO, 2013, 1049 s. ISBN 978-90-257-0807-1.

MAREŠ, P. 1999. Sociologie nerovnosti a chudoby. Praha : Sociologické nakladatelství, 1999, 248 s. ISBN 80-85850-61-3.

SEN, A. 1981. Poverty and Famines. New York : Oxford University Press, 1981, 257 p. ISBN 0-19-828426-8.

SCHWARZ, P. - KOVÁČIK, M. 2012. Impact of selected indicators on risk poverty rate in EU and SR. In Acta Oeconomica universitatis Selye, vol. 1, 2012, no. 1, pp. 155-162. ISSN 1338-6581.

STRATEGY 2020. 2010. A strategy for smart, sustainable and inclusive growth. Brussels : European Commission, 2010, 32 p.

TOWNSEND, P. 1979. A survey of household resources and standards of living. Middlesex : Penguin Books, 1979, 1216 p. 